\title{
Household Production of Ceramic Water Filters in Western Rajasthan, India
}

\author{
Sandeep Gupta \\ Graduate Student, Mechanical Engineering Department \\ Indian Institute of Technology Jodhpur, Jodhpur \\ gupta.5@iitj.ac.in \\ Amrita Kaurwar \\ Graduate Student, Mechanical Engineering Department \\ Indian Institute of Technology Jodhpur, Jodhpur \\ kaurwar.1@iitj.ac.in \\ Muhammad Sharif \\ Associate Professor, Aerospace Engineering and \\ Mechanics Department \\ University of Alabama, \\ msharif@eng.us.edu
}

\author{
Raj Kumar Satankar \\ Graduate Student, Mechanical Engineering Department \\ Indian Institute of Technology Jodhpur, Jodhpur \\ pg201383005@iitj.ac.in
}

Usha Aravind

Science Coordinator, Advanced Center of Environmental Studies and Sustainable Development Mahatma Gandhi University ukaravind@gmail.com

\author{
Anand Plappally* \\ Assistant Professor, Mechanical Engineering Department \\ Indian Institute of Technology Jodhpur, Jodhpur \\ anandk@iitj.ac.in
}

*Corresponding Author

Abstract -- Frustum shaped clay ceramic water filters are being manufactured by the potters of the Thar Desert in India for household use. The clay composite consists of a homogeneous mixture of equal volume of clay and sawdust. A low-cost manual press, to form the clay composite into frustum shape, is developed by the present authors. This article elaborates critical investigation of the specific traditional clay-firing technique used, to achieve the required functionality and material property of the filters. Household based manufacturing of these filters is found to be markedly different from factory based production by firing process. The functional features of the clay ceramic filter, such as microbial filtration rate, flow rate, and compressive strength, are evaluated and presented. An E. coli bacteria removal efficiency of more than $99 \%$ is achieved using these clay ceramic water filters. Optimal filtration rates are achieved between ambient temperatures ranging from $30^{\circ} \mathrm{C}$ $4^{\circ} \mathrm{C}$.

Index Terms - Ceramic Water Filter, Filter Press, Filtration, Global Health

\section{INTRODUCTION}

Water purification to acquire potable water is a major challenge for the present day civilization. Many water purification methods and technologies have been developed and employed over the years ${ }^{1}$. Most of these methods are cost and energy intensive and are not easily adaptable to the rural population of the developing world ${ }^{2}$. A very simple and effective method using water filtration through clay-ceramic pots have been used over the years in many rural parts of the developing world ${ }^{1}$. The ultrafine pore passages with high tortuosity in the clay material trap most of the non-soluble contaminants and bacteria (> 99\%). A reasonable volumetric production $(>600$ $\mathrm{ml} / \mathrm{hr}$ ) of safe potable water can be obtained by this method ${ }^{3}$. A nonprofit organization "Potters for 
Peace" based in Boulder, Colorado, USA has been promoting the clay ceramic pot impregnated with a colloidal silver lining in central America since the early 1980s. The water filter propagated by Potters for Peace is viewed as one of the most sustainable solutions for household drinking water purposes ${ }^{4,5}$. This technology is famed due to its ability to showcase considerable reduction in diarrhea cases ${ }^{5-7}$. India has the largest diarrhea related mortality ${ }^{8}$. Diarrhea is caused by ingestion of microbe contaminated water.

Potters from Western Rajasthan, India are well acquainted with the manufacturing of off-white water storage pots ${ }^{9}$. Percolating decontaminated/filtered water drips down these off-white water pots ${ }^{10}$ which can be collected and used as potable water. Filtration by gravity is a low cost, energy efficient operation ${ }^{1}$. Frustum shaped ceramic water filters have showcased log removals of 2 to 4 while filtering water contaminated with microbes such as E. Coli ${ }^{1,11-13}$. This filtration technology, however, does not perform well in case of virus filtration ${ }^{12}$. Plappally carried out an extensive review on clay ceramic based water filters ${ }^{14}$. Plappally and Lienhard reviewed cost and microbial filtration efficacy of these clay ceramic water filtration devices ${ }^{1}$. Hunter asserted that these clay ceramic water filters are most effective long-term water filtration solutions for households in developing nations ${ }^{15}$.

During emergencies like tsunami and floods in Sri Lanka and Dominican Republic, such clay ceramic filters were used for ensuring drinkability of water ${ }^{16}$. These filters had a frustum shape with a height of $26 \mathrm{~cm}$ and a base diameter of $20 \mathrm{~cm}^{17}$. This frustum shaped 10-15 liter capacity water filter is sufficient for drinking water requirements of a nuclear families ${ }^{18,19}$. The literature on hydraulic modeling suggests a filtration rate of 1-3 liters per hour through these filters ${ }^{1,4,20}$.

Potters are a pertinent facet of rural India. Potter can be equipped with the clay ceramic water filtration technology of Potter for Peace to provide one-stop solution for drinking water purification ${ }^{18,21}$. A nonprofit organization "Rupayan Sansthan" introduced this technology with a name G-Filter in Western Rajasthan ${ }^{22-24}$. The G-Filter was introduced keeping in mind skill development, local accessibility, potter community sustenance, and inexpensive and efficient rural water services in Western Rajasthan ${ }^{25}$. G-Filter is found to be a solution for drinking water woes of dispersed communities with no-piped water supplies ${ }^{26}$. One impediment for G-Filter sustenance is whether local people are willing to pay for G-Filters when other drinking water options are available ${ }^{27}$. Furthermore, various other energy intensive point of use water filtration technologies and bottled water have already entered households in India ${ }^{28}$, despite long term health risks due to human ingestion of toxic leachants from polyethylene terephthalate bottles ${ }^{8,29}$.

A typical G-Filter is shown in Fig. 1. A 20 liter clay container supports a 9 liter filter receptacle and cools the filtrate collected within. The clay container is made using the traditional technique for manufacturing water storage pots ${ }^{9}$. 


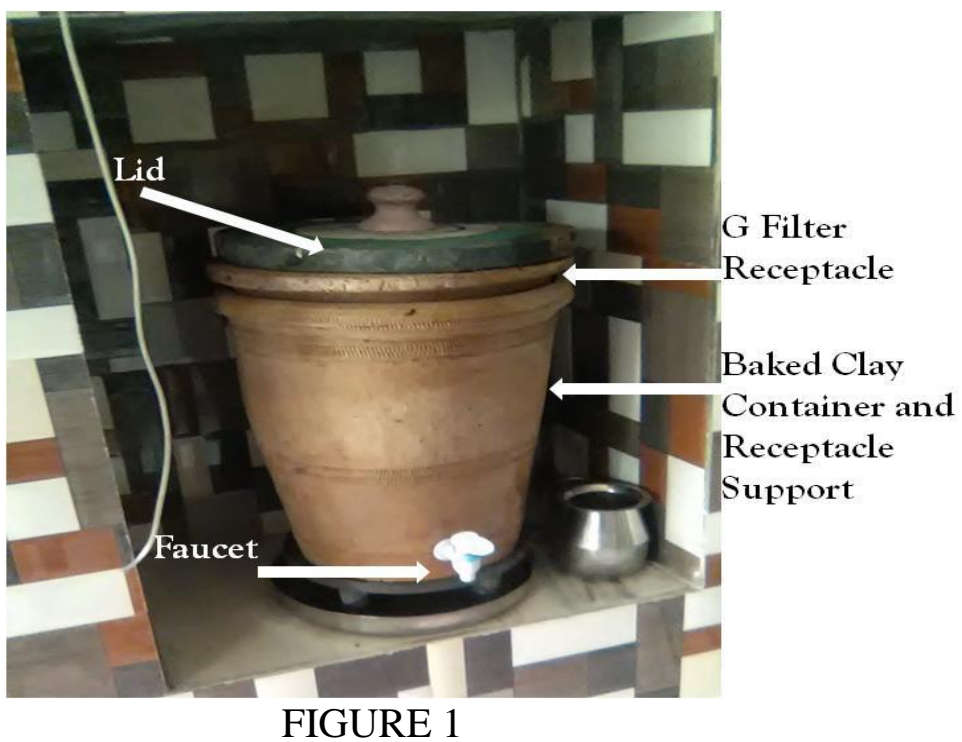

THE G FILTER SETUP IN A HOUSE AT BANAD VILLAGE, JODHPUR

In India, pottery is a community based profession ${ }^{30,31}$. This skill is passed from generation to generation. The imminent thought of possible loss of family profession due to the adaptation of other water filtration/purification methods, prompted researchers working towards this ceramic water filter project to arrest the feasibility of a cottage industry based factory for clay-ceramic water filter production ${ }^{32,33}$. The objective of this project will be to preserve and continue the community profession and instill the factory based water filter manufacture ${ }^{34}$ technology to the local potter community. In western Rajasthan, traditionally the potters practice open firing and an up-draught open hearth furnace ${ }^{31,35}$ for firing the filter, which will differ from the factory mode of water filter manufacture ${ }^{18,36,3,37}$.

This article reports the process of clay ceramic water filter manufacturing by potter households in western Rajasthan, India. This includes studying local (Rajasthan potters) know-how of processing raw materials and sintering clay artifacts and substituting it for factory mode of filter production processes practiced in different locations of the world ${ }^{37-40}$. Finally the clay ceramic filters manufactured as proof-of-concept are assessed for its microbial removal effectiveness and load bearing capacities.

\section{METHODOLOGY}

\section{Forming the Soil to a Shape}

The potters in Western Rajasthan are acquainted with rotating wheel based pottery ${ }^{41}$. The process of manufacture of the clay ceramic water filter receptacle is distinct. Pottery in Western Rajasthan is still untouched by mechanization ${ }^{42}$. Salty raw clay is mined from Raital and Mokalsar near Jodhpur, Rajasthan ${ }^{31}$, which - is then powdered ${ }^{30}$. The women folk (irrespective of the location of potter across India) sieve the clay using a household sieve $(3 \mathrm{~mm} \times 3 \mathrm{~mm})$. Potter for Peace recommends a sieve size in the range $0.18 \mathrm{~mm}-2 \mathrm{~mm}^{43}$. If the salt content in the clay is not sufficient $\left(0.02 \%\right.$ by volume), additional salt is added into the clay ${ }^{29}$. Addition of salt is considered to make the clay ceramics more load bearing, whiter in color, and functionally better refrigerators of water ${ }^{31}$. Local artisans believe that addition of salt in clay influence the sintering rates of clay 
ceramics. Traditionally, equal volumes of soil and organic matter (saw dust) are kneaded together to manufacture structurally stable construction materials in Western Rajasthan ${ }^{44}$. Sieving of sawdust is performed with the same sieve used to for the powdered salty clay. This is analogous to the Potter for Peace method of preparing the clay-sawdust mixture for manufacturing the filter greenware ${ }^{3,45}$. In this study, a uniform mix of sawdust and salty clay taken in equal volumes is added with water, equivalent to $70 \%$ by volume of the mix, to form the disk shaped composites. The composite is kept overnight a moist cloth covering ${ }^{46}$. The composite is press-formed to frustum shape using a 30 ton press (MEC Ltd, India) ${ }^{4}$. The frustum shaped aluminum molds (used to press form the green wares) are covered with a 96 in diameter plastic bag to prevent formed green body from sticking to the mold wall ${ }^{14}$. It should be noted that several versions of frustum shaped water filter presses are available and are being used around the world ${ }^{18,38,47}$. A photograph of the indigenous filter press built to make a nine liter filter green body of the composite mix is shown in Fig. 2.

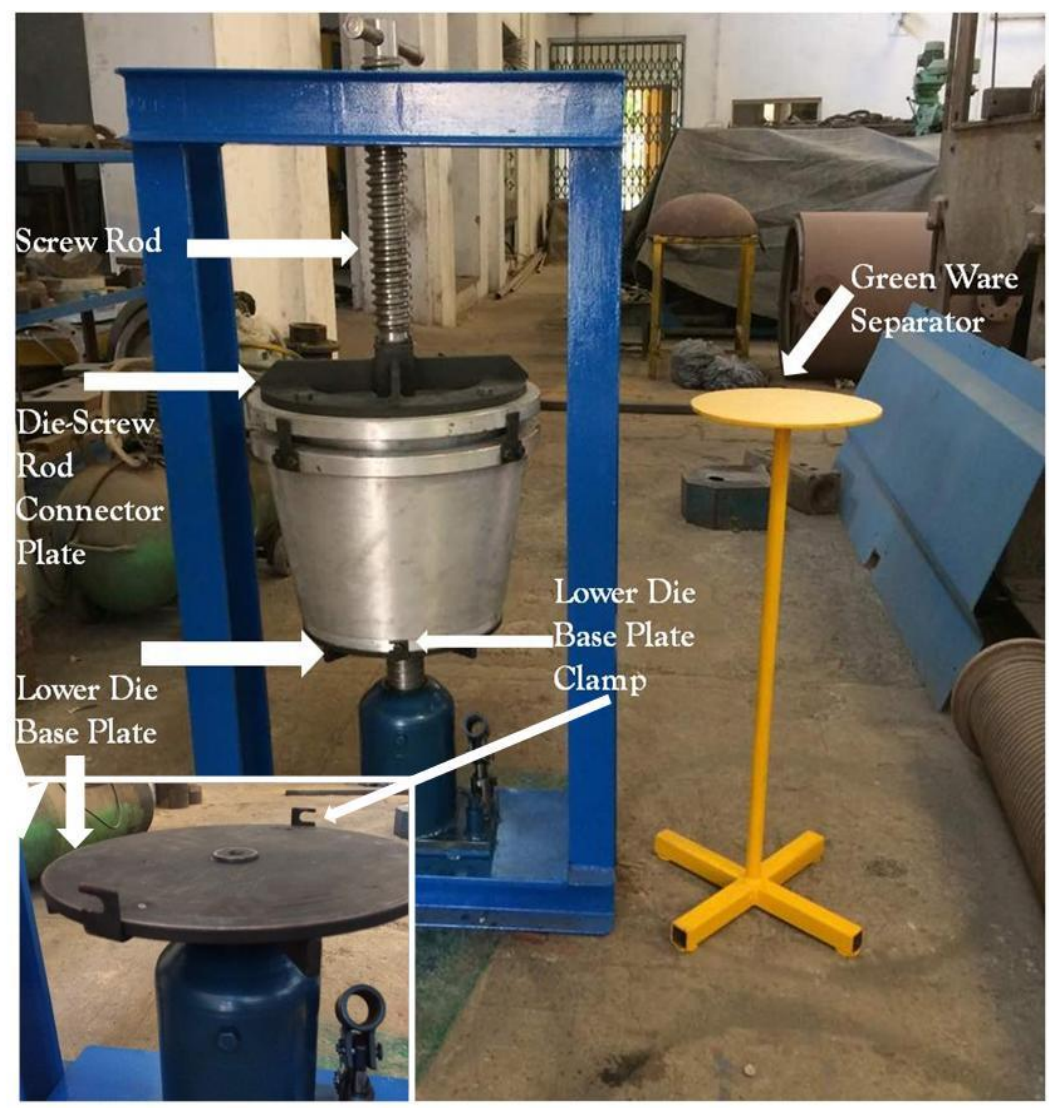

FIGURE 2

THE CERAMIC WATER FILTER PRESS DEVELOPED IN THE LABORATORY (COURTESY: Y\&CO, JODHPUR, RAJASTHAN, INDIA)

The green ware thus formed is $23 \mathrm{~cm}$ high and has a base diameter of $25.5 \mathrm{~cm}$. These dimensions were set according to a commercially available plastic bucket of $38 \mathrm{~cm}$ height. The green ware separator illustrated in Fig 2 was utilized to retrieve the filter green ware. The filter green ware 
once formed was kept for 2 days in ambient conditions and then dried under direct sunlight for 3 days in this work. The age of drying, its rate and methodology influences the structure and function of the final sintered ceramic being produced ${ }^{48}$.

\section{Firing Process Development}

Once dried, the green ware is fired in a vertical open hearth furnace (circular shape) of $5 \mathrm{ft}$ radius and $5 \mathrm{ft}^{\text {height }}{ }^{31}$. This up draught firing furnace as illustrated in Fig. 3 was introduced in Jodhpur in $1960 \mathrm{~s}^{31}$. The firing and heating chamber is separated by used truck leaf spring blades. The size of the firing box is $0.4572 \mathrm{~m} \times 0.4572 \mathrm{~m}$. Volume of the heating chamber is 1.75 times of the firing chamber. The green-wares and the furnace are covered with rubbles of pottery to achieve this volume ratio. The kiln wall is tied using an iron belt to improve its structural integrity ${ }^{49}$. The green wares are kept $0.61 \mathrm{~m}$ above the ground in inverted position while firing ${ }^{31,49}$. The local potters fired the dried green ware at the same temperature as they used to traditionally fire pure clay flower vases. These temperatures are similar to those set in factory mode sintering ${ }^{17,50}$.

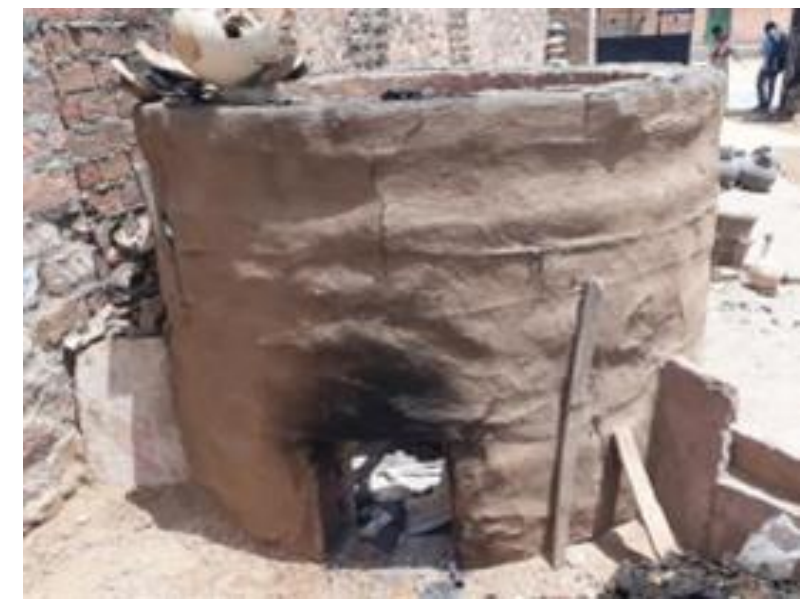

FIGURE 3

THE UP-DRAUGHT FURNACE SAR VILLAGE, JODHPUR, RAJASTHAN, INDIA

Locally available cow dung cakes, organic waste (dried twigs or leaves), waste wood, and sawdust are used as fuel for the furnace ${ }^{31}$. The firing should be performed at a temperature range that precludes cracking possibility. During the sintering trials, some of the filter green wares cracked due to thermal stress ${ }^{51,52}$. Potters from the three villages reported this observation with a frequency of 1 in every 45 filter green-wares fired.

In order to monitor the temperature variation in the furnace, continuous measurement of the temperature variation in the furnace during the firing process was conducted with an IR thermometer and $\mathrm{K}$ type thermocouple capable to measure in the range $-50^{\circ} \mathrm{C}-1850^{\circ} \mathrm{C}$ ( $\mathrm{HTC}$ IRX-68). $\mathrm{K}$ type thermocouples were placed inside the furnace at different points to get an overall average time history of the temperatures during the firing process. The measured sintering temperature time history, which precludes the emergence of cracking, is plotted in Fig. 5. The firing time illustrated in Fig. 4 ( $\sim 230 \mathrm{~min}$.) is comparatively shorter compared to factory based 
ceramic water filter firing thus conserving lot of energy and fuel ${ }^{37,39}$. Firing forty five filter green bodies consumes $100 \mathrm{~kg}$ of wood and $100 \mathrm{~kg}$ of sawdust in an updraught (5 ft by $5 \mathrm{ft}$ ) furnace ${ }^{31}$. Once the firing process is completed, the filters are retrieved after overnight cooling. The filters are left unglazed and utilized for the field experiments.

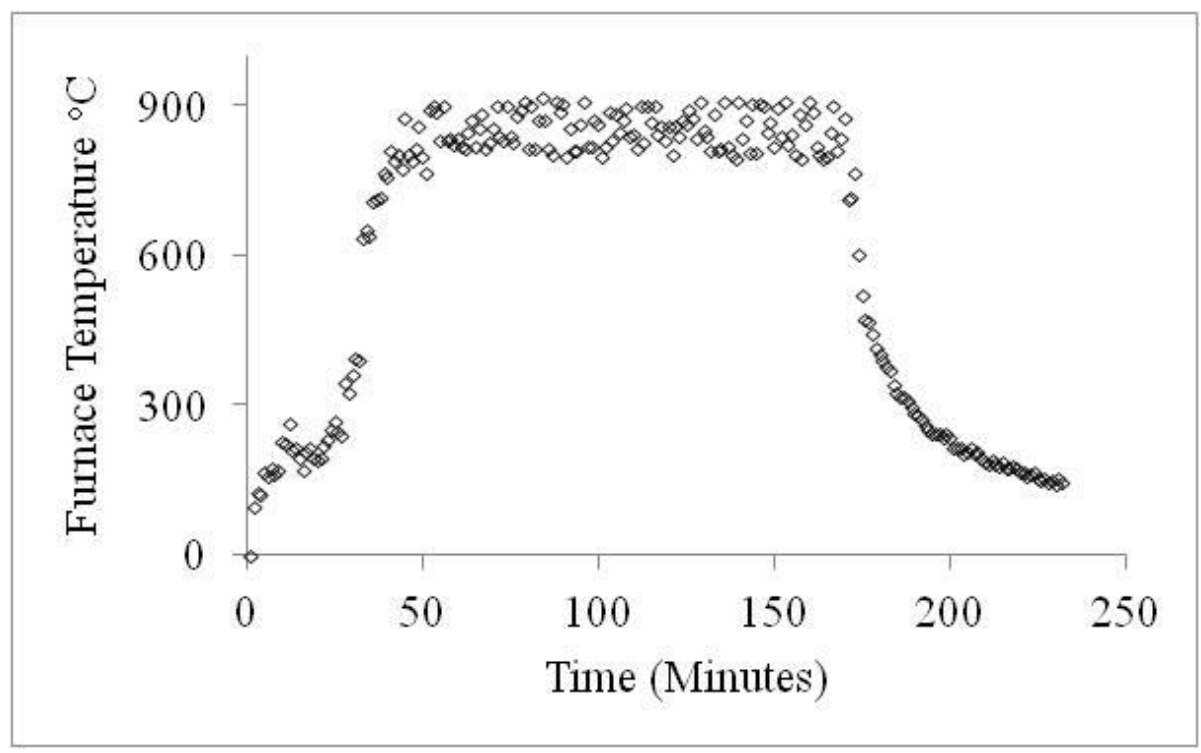

FIGURE 4

TIME HISTORY OF MEASURED OVERALL TEMPERATURE VARIATION IN THE FURNACE THAT PRECLUDES CRACKING OF THE FILTERS

\section{FunCtionality ASSESSMENT OF THE MANUFACTURED Filters}

Various functionalities of the manufactured $G$ Filter were systematically evaluated. The volumetric filtration rate, compressive load bearing capability, and microbial removal rates were tested and quantified to assess the characteristics of the water filters. These are discussed in the following sub-sections.

\section{Flow Measurement}

The discharge from the G- filter is measured in fully filled condition. Prior to flow measurement experiment, the filters were soaked and saturated with ultra-pure water ${ }^{4}$. The filtrate was collected from four distinct filters manufactured at Banad, Sar, and Salawas villages in Jodhpur. These filters slightly differ in raw materials, construction methods, and firing process depending on the locality of production. A graduated beaker was kept beneath each of the fully filled water filters suspended from a test frame. These four filters were randomly selected. The filtrate is the water, which is collected during the first hour of filtration running in a fully filled condition. The time measurement was performed using a digital stop watch (Casio ${ }^{\circledR}$ A158WA-1DF). The water was collected from the four filters on different days of the year to simulate distinct ambient temperature conditions. 
Percolation rates of water from the four selected G Filters is plotted in Fig. 5 as a function of the ambient temperature ${ }^{53}$. In the first hour, the fully filled filters produce an average of $600-950 \mathrm{ml}$ of filtrate ${ }^{54}$. Similar results have been observed in other frustum shaped ceramic water filter variants across the globe ${ }^{20,50}$. These filtrate productions were in the range 1-3 1/hr ${ }^{1}$. From Fig. 5, it is observed that the maximum percolation rate occurred at temperature range between $30^{\circ} \mathrm{C}-40^{\circ} \mathrm{C}$. Water filtration rate vary with local ambient temperature. All filters showcased a dip in filtration rates when the ambient temperature goes beyond $35^{\circ} \mathrm{C}$ (except for filter 1) as illustrated in Fig. 5 .

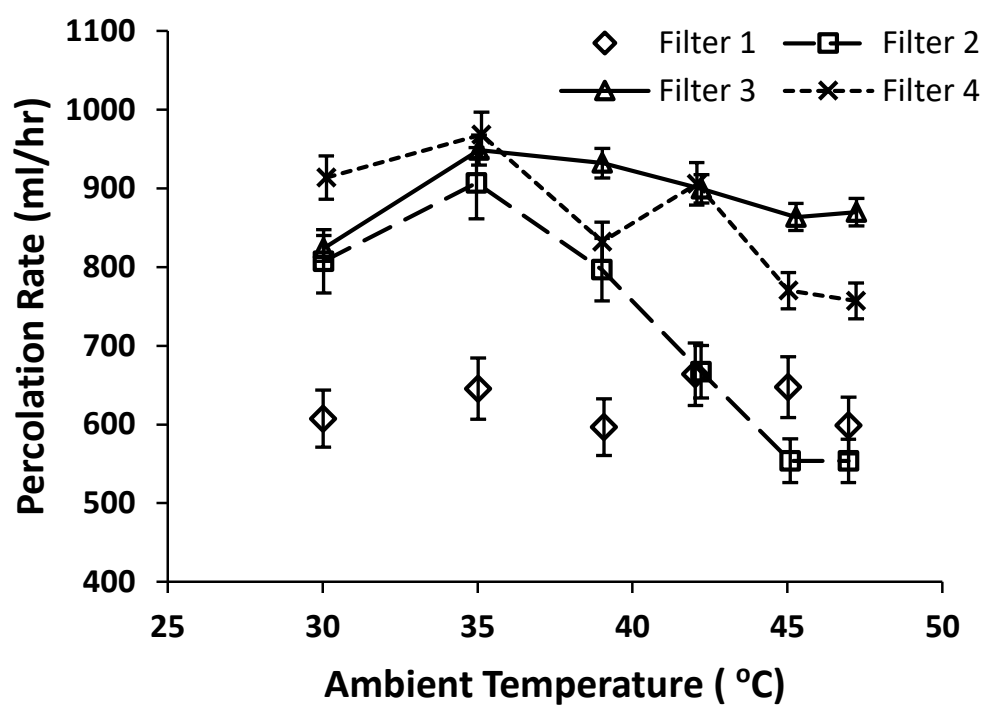

FIGURE 5

THE PERCOLATION RATE OF THE G-FILTER ( $\mathrm{n}=11)$ IN COMPLETELY FILLED CONDITION AS A FUNCTION OF THE AMBIENT TEMPERATURE

\section{Compressive Strength}

For brittle ceramics, the compressive strength is approximately fifteen times the tensile strength ${ }^{48}$. The compressive tests were performed according to the ASTM 1358 standards ${ }^{17}$. Propagation of cracks in ceramics during compressive loads is parallel to axis of applied compressive load ${ }^{55}$. The specimens for the strength tests were prepared from the circular base of the eleven randomly selected sintered $\mathrm{G}$ filters. A static axial load at a rate of $0.1 \mathrm{Ns}^{-1}$ is applied to the $35 \mathrm{~mm}$ long sample with a cross section of $15 \mathrm{~mm} \times 15-\mathrm{mm}^{17,50}$. The samples were tested for compression on a Universal Material Testing Machine (Model EZ-50, Lloyd Instruments, Germany). It should be noted that inherent cracks or inhomogeneity in the porous clay ceramics increase during compression resulting in powder formation ${ }^{48,55,56}$. The applied compressive loads overcome the strong chemical bonding between the sintered material particles to form these powders ${ }^{57}$. Tests were conducted at a temperature of $300 \mathrm{~K}$ and a relative humidity of $20-25 \%$. It is known that compressive failure stress of clay ceramic materials is a polynomial function of their densities ${ }^{56}$. It is therefore pertinent to observe the little variations in density owing to craftsmanship of the potters from Banad, Sar and Salawas villages. Therefore density also was calculated by dividing the mass of the $35 \mathrm{~mm}$ thick ceramic sample to its geometrical volume. Mass of the samples are 
measured using a digital weighing balance (Citizen CG3S, M/s Indian Equipments Co., Jaipur, India).

Compressive strength of ceramic filter material depends on the heterogeneous material character ${ }^{58}$. The eleven G Filter green wares in the up draught kiln contain pre-existing non-elastic deformation or crack forming inhomogeneity (completely oxidizable organics) ${ }^{17,57}$. The compressive strength of the tested specimens are plotted in Fig. 6 as a function of the density of the specimens in which, a derived equation for a polynomial fit of the data with high goodness of fit $(R)$ is also reported. The polynomial relationship of the compressive strength $\sigma_{c}$ of the G Filter material with its density $\rho$ conforms to similar relationships derived by other researchers ${ }^{14,17}$. It is to be noted that the density of ceramic filter material depends on the manufacturing process and sintering parameters ${ }^{59}$. An increase in the density of the clay ceramics accompanies an increase in the compressive strength of the ceramic ${ }^{59}$.

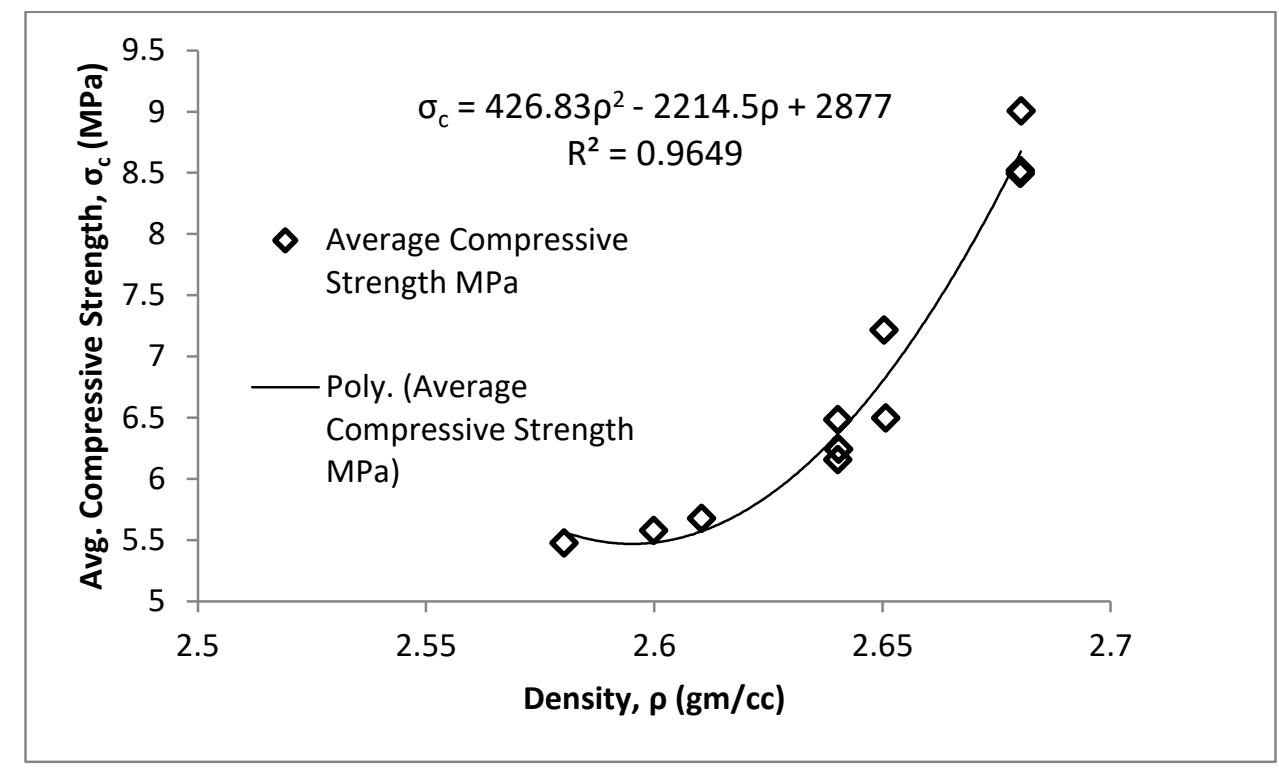

FIGURE 6

COMPRESSIVE STRENGTH AS A FUNCTION OF DENSITY OF G FILTER MATERIAL 50

\section{Microbial Filtration}

E. coli (Escherichia coli) is an indicator bacterium for occurrence of bacterial pathogens and also for fecal contamination ${ }^{60,61}$. E. coli concentration tests in the pre- and post-filter water samples were conducted according to ISO 9308-1:2014 framework ${ }^{59}$. One Shot ${ }^{\circledR}$ TOP10 E. coli (ThermoFisher Scientific, India) cells (similar to the E. coli DH10B strain) was used for spiking the concentration in the ultra-pure water. The pure water was supplied by M/s Tomar Scientific, Jodhpur, India. This brand of E. coli is commonly available for laboratory experiments such as cloning, and plasmid propagation (Thermo-Fisher Scientific, India) ${ }^{62}$. One Shot ${ }^{\circledR}$ TOP10 E. coli strain was grown in Miller's LB Broth at ambient condition overnight ${ }^{62}$. Concentrated solution of the E. Coli, diluted with 3 liters of microbial contaminant free distill water was stored until use at $-75^{\circ} \mathrm{C}$. This solution was prepared prior to the day of the filtration tests. The pre-filtrate sample 
was prepared by spiking required E. Coli stock (mentioned above) into a constantly stirred 30 liters water tank. The experimental set-up is diagrammatically represented in Fig 7. The complete microbial filtration test set up is kept within a plastic structure. The initial one liter of the filtrate was discarded to prevent initial dilution of filtrate due to their saturation. Saturated filter receptacles are used to simulate operational conditions of the filter. The beaker is cleaned with ethanol followed by rinsing with deionized water and $500 \mathrm{ml}$ of filtrate was collected. The number of viable cells in the contaminated water within the $G$ filters and the filtrate was determined by proper dilution in ultrapure water. Further plating was performed on Miller's LB agar plates. These plates were kept overnight in incubators at $37^{\circ} \mathrm{C}$. The colonies were counted after incubation at $37^{\circ} \mathrm{C}$ and this information was used to calculate viable cells in the respective water samples.

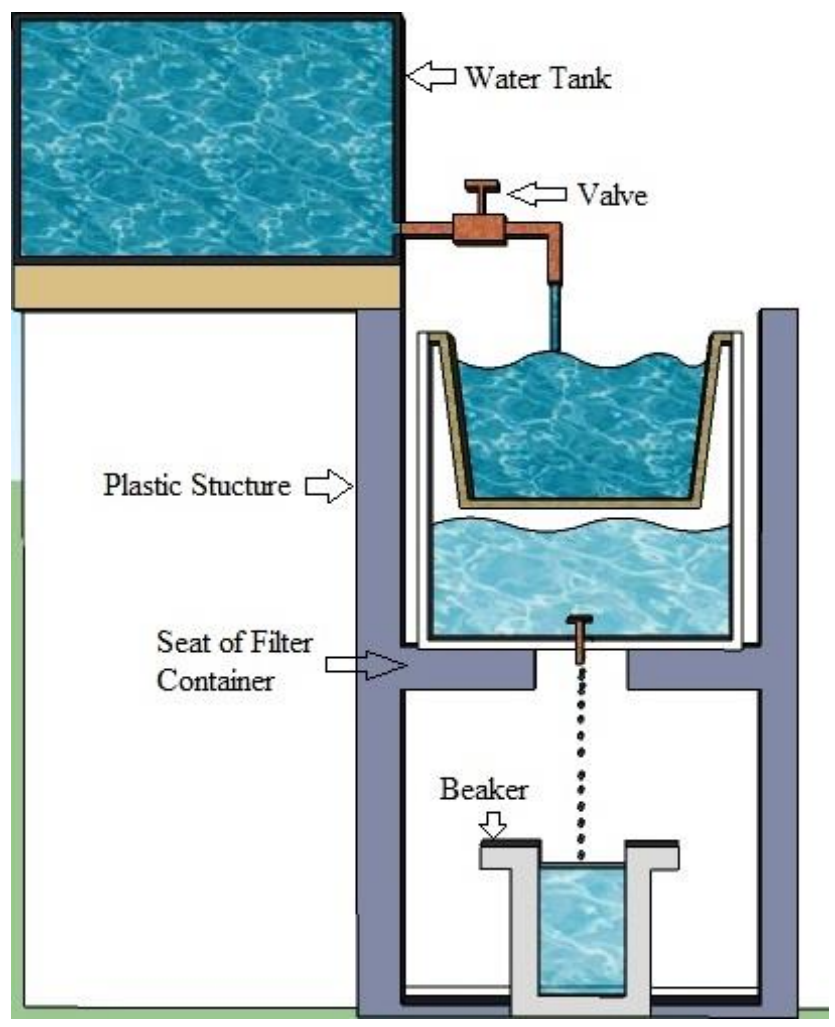

FIGURE 7

SCHEMATIC PRESENTATION OF THE MICROBIAL FILTRATION SET-UP

The numbers of viable cells in the pre- and post-filter suspensions were counted. The efficiency of E. coli filtration was calculated as ${ }^{18}$,

$$
\eta_{E . \text { Coli }}=1-N_{f} / N_{p f}
$$

where $N_{f}$ is the number of viable cells per milliliter of filtrate and $N_{p f}$ is the number of viable cells per milliliter in the pre-filter sample. The log reduction value is defined as ${ }^{14,18}$,

$$
L R V=\log _{10}\left(N_{p f} / N_{f}\right)
$$


A contaminated water suspension with almost around $10^{8} \mathrm{cells} / \mathrm{ml}$ was used in the pre-filter sample. Similar levels of contamination $\left(10^{6}-10^{8}\right.$ cells $\left./ \mathrm{ml}\right)$ have been observed in the Yamuna river water, which is a major source of drinking water in Northern India ${ }^{63}$. This fecal coliform contaminant level is far beyond the drinking water quality standards set by World Health Organization $(\mathrm{WHO})^{64}$. The E. coli filtration experiments were performed on the three G Filter. Each of these G Filters were tested four times using a produced contaminated solution of E.coli as mentioned above. Table 1 shows the efficiencies of the three $\mathrm{G}$ filters tested.

TABLE I

RESULTS OF E. COLI FILTRATION EFFICIENCY OF THE G FILTERS

\begin{tabular}{|c|c|c|c|c|}
\hline $\begin{array}{l}\text { Pre-filter Concentration (No. of } \\
\text { Cells } / \mathrm{ml} \text { ) }\end{array}$ & $\begin{array}{l}\text { Filtrate Concentration (No. of } \\
\text { Cells } / \mathrm{ml} \text { ) }\end{array}$ & Pre-Filter Conc./Filtrate Conc. & $\begin{array}{c}\text { Efficiency }\left(1-N_{f} /\right. \\
\left.N_{p f}\right)\end{array}$ & $\begin{array}{l}\text { Log Reduction } \\
\text { Value }(L R V)\end{array}$ \\
\hline $6.0 \times 10^{8}$ & $1.6 \times 10^{6}$ & 375.0 & 0.9973 & 2.5 \\
\hline $4.0 \times 10^{8}$ & $6.0 \times 10^{6}$ & 666.6 & 0.9985 & 2.8 \\
\hline $2.4 \times 10^{8}$ & $4.5 \times 10^{6}$ & 533.3 & 0.9981 & 2.7 \\
\hline
\end{tabular}

\section{CONCLUSION}

Household mode of manufacturing $\mathrm{G}$ filters is discussed. This mode of manufacturing varies from the factory mode ${ }^{18,19,33,65}$. These clay ceramic filters are considered to be one of the sustainable drinking water procuring solutions in developing countries ${ }^{66}$. Women folk of the potter families in India are knowledge bearers of the type and size of clay for specific pottery artifact. These filters are sintered using the indigenous firing technique. The instantaneous filtration rate through the $\mathrm{G}$ Filter is ambient temperature dependent. The maximum filtration rate of $\mathrm{G}$ Filter was observed between the temperature range of $30^{\circ} \mathrm{C}$ and $40^{\circ} \mathrm{C}$. Manufactured filters with low density materials have lower compressive strength. It is reiterated that a polynomial function exists between the density and compressive strength of the G Filter material ${ }^{17}$. The microbial treatment efficacy of such filters is at par with clay ceramic water filter produced in factories elsewhere ${ }^{5,38}$. The implication is that potter households dispersed at different location in Western Rajasthan and across India can locally and individually manufacture $G$ filters and distribute to their surroundings. This reduces the cost of transporting water filters to remote locations in rural India.

\section{ACKNOWLEDGMENTS}

The authors would like to thank potters of Jodhpur Mr. Razzak Khan (Banad village), Mr. Bhike Khan and Mr. Faroukh Khan (Sar Village), Mr Iqbal Khan (Salawas), Mr. Devaiah Soyam (Chhattisgarh) and Mrs. Naini Baanu (Banad Village) for their support during the research. The authors would also like to thank Department of Science and Technology, India for funding partially the research through their grant No. YSS/2014/000576. The support from Mr. Ajay Kumavat, Mr. Subham Teji, Mr. Lovelesh Dave, Ms. Ankisha Vijay, and Mr. Rohit Singh, is greatly acknowledged. 
International Journal for Service Learning in Engineering, Humanitarian Engineering and Social Entrepreneurship Vol. 13, No. 1, pp. 53-66, Spring 2018

ISSN 1555-9033

\section{REFERENCES}

1. Plappally, A.K., and J.H. Lienhard V. "Costs for Water Supply, Treatment, End-Use and Reclamation." Desalination and Water Treatment 51, no. 1-3 (2013). doi:10.1080/19443994.2012.708996.

2. Plappally, A.K., and J.H. Lienhard V. "Energy Requirements for Water Production, Treatment, End Use, Reclamation, and Disposal." Renewable and Sustainable Energy Reviews 16, no. 7 (2012). doi:10.1016/j.rser.2012.05.022.

3. Plappally, A, A Soboyejo, N Fausey, W Soboyejo, and L Brown. "Stochastic Modeling of Filtrate Alkalinity in Water Filtration Devices: Transport through Micro/nano Porous Clay Based Ceramic Materials." Journal of Natural and Environmental Sciences 1, no. 2 (2010): 96-105.

4. Plappally AK, Yakub I, Brown LC, Soboyejo WO, Soboyejo ABO. "Theoretical and Experimental Investigation of Water Flow through Porous Ceramic Clay Composite water Filter." Fluid Dynamics and Materials Processing 5, no. 4 (2009).

5. Sobsey, Mark D, Christine E Stauber, Lisa M Casanova, Joseph M Brown, Mark A Elliott, and North Carolina. "Point of Use Household Drinking Water Filtration: A Practical, Effective Solution for Providing Sustained Access to Safe Drinking Water in the Developing World." Environ. Sci. Technol. 42, no. 12 (2008): 4261-67. doi:10.1021/es702746n.

6. Halem, D. Van. "Ceramic Silver-Impregnated Pot Filters for Household Drinking Water Treatment in Developing Countries.” Delft University of Technology. Delft University of Technology, 2006. doi:10.2166/ws.2007.142.

7. Fewtrell, L, Kaufmann, RB, Enanoria, W, Haller, L and Colford, Jr., and J.M. "Water, Sanitation, and Hygiene Interventions to Reduce Diarrhea in Less Developed Countries: A Systematic Review and MetaAnalysis." Lancet Infect Dis 5 (2005): 42-52.

8. Lantagne D. "Water Treatment Innovations in Developing Regions of the World." UChicago CISSR Conference, 2010. https://www.youtube.com/watch?v=-abrjf0wgow.

9. Kaurwar, Amrita, Raj Satankar, Sandeep Gupta, Usha Aravind, Kuldeep Kothari, Alfred B Soboyejo, and Anand Plappally. "Functional Demarcation of Traditional Off-White Colored Water Pots Manufactured from Rajasthan Clayey Soils and Red Colored Water Pots from Gujarat Clayey Soils Using Spectrographic, Cooling and Strength Studies--A Case Study from Jodhpur, Rajasthan, Indi." MRS Advances, 2017, 1-6. doi:10.1557/adv.2017.127.

10. Sikdar, Mithun, and Pritish Chaudhuri. "Pottery Making Tradition among the Prajapati Community of Gujarat, India." Euras. J Anthropol. 6, no. 1 (2015): 1-14.

11. Bielefeldt, Angela R., Kate Kowalski, and R. Scott Summers. "Bacterial Treatment Effectiveness of Pointof-Use Ceramic Water Filters." Water Research 43, no. 14 (2009): 3559-65. doi:10.1016/j.watres.2009.04.047.

12. Laan, H. Van der, D. van Halem, P. W M H Smeets, A. I A Soppe, J. Kroesbergen, G. Wubbels, J. Nederstigt, I. Gensburger, and S. G J Heijman. "Bacteria and Virus Removal Effectiveness of Ceramic Pot Filters with Different Silver Applications in a Long Term Experiment." Water Research 51 (2014): 47-54. doi:10.1016/j.watres.2013.11.010.

13. Simonis J J, Basson A K. "Evaluation of a Low-Cost Ceramic Micro-Porous Filter for Elimination of Common Disease Microorganisms." Physics and Chemistry of the Earth, Parts A/B/C 36, no. 14-15 (2011). https://doi.org/10.1016/j.pce.2011.07.064.

14. Plappally, A. K. "Theoretical and Empirical Modeling of Flow, Strength, Leaching and Micro-Structural Characteristics of V Shaped Porous Ceramic Water Filters." Columbus, 2010. https://etd.ohiolink.edu/pg_10?0::NO:10:P10_ETD_SUBID:71963.

15. Hunter, Paul R. "Household Water Treatment in Developing Countries: Comparing Different Intervention Types Using Meta-Regression.” Environmental Science, 43, no. 23 (2009): 8991-97. doi:10.1021/es9028217.

16. Lantagne, Daniele, and Thomas Clasen. "Point-of-Use Water Treatment in Emergency Response." Waterlines 31, no. 1-2 (2012): 30-52. doi:10.3362/1756-3488.2012.005. 
International Journal for Service Learning in Engineering, Humanitarian Engineering and Social Entrepreneurship Vol. 13, No. 1, pp. 53-66, Spring 2018

ISSN 1555-9033

17. Plappally, A. K., Yakub, I., Brown, L. C., Soboyejo, W. O., Soboyejo, A. B. O. "Physical Properties of Porous Clay Ceramic-Ware.” J. Eng. Mater. Technol. 133 (2011): 31004-1-0-1-9.

18. Plappally, Anand, Haoqian Chen, Wasiu Ayinde, Samson Alayande, Andrew Usoro, Katie C Friedman, Enoch Dare, et al. "A Field Study on the Use of Clay Ceramic Water Filters and Influences on the General Health in Nigeria." J Health Behav \& Pub Health 1, no. 1 (2011): 1-14.

19. Brown, Joe, Mark Sobsey, and Sourya Proum. "Use of Ceramic Water Filters in Cambodia." Water and Sanitation Program, 2007. http://www.unicef.org/eapro/WSP_UNICEF_FN_CWP_Final.pdf.

20. Schweitzer, Ryan W., Jeffrey A. Cunningham, and James R. Mihelcic. "Hydraulic Modeling of Clay Ceramic Water Filters for Point-of-Use Water Treatment.” Environmental Science and Technology 47, no. 1 (2013): 429-35. doi:10.1021/es302956f.

21. Sundaram, Aravind, and Bishakh Bhattacharya. "Earthenware Water Filter: A Double Edged Sustainable Design Concept for India." In ICord, edited by A. Chakrabart and R. Prakash, 1421-31. Lecture Notes in Mechanical Engineering. Springer, India, 2013. doi:10.1007/978-81-322-1050-4_114.

22. Gupta, S, A Kaurwar, R K Satankar, K Usha, and A K Plappally. "Flow, Filtration and Petrophyscial Properties of Ceramic Plate Ware Gravity Water Filter and Its Variation with Long Term Cyclic Water Loading." In Proceedings of From Pollution to Purification (International Conference on Water 2016 ). Organized by IUIC, ASCEED \& School of Environmental Sciences , Mahatma Gandhi University, Kottayam, 2016.

23. Iqbal, Mohammed. “Taking on a 'drinking' Problem Head-on in Rajasthan.” The Hindu. May 22, 2017. http://www.thehindu.com/todays-paper/tp-national/tp-otherstates/taking-on-a-drinking-problem-head-onin-rajasthan/article18522033.ece.

24. Soyam, Devaiah, Praveen Suthar, Bhagya Wardhan, Sandeep Gupta, Amrita Kaurwar, Raj Kumar Satankar, Kuldeep Kothari, and Anand K Plappally. "G-Filters for Water Filtration : Technology for Individual Potter." In India International Science Fest 2016, 1. New Delhi, India: Unnat Bharat Abhiyan, 2016.

25. Krishnamurthy, Mira. "The Improved Village Pottery in the Rural Reconstruction of India." Transactions of the Indian Ceramic Society 13, no. 3 (1954): 160-63.

26. Urs, Kshithij, and Richard Whittell. Resisting Reform? Water Profits and Democarcy. First. New Delhi, India: SAGE Publications India Pvt. Ltd., 2009.

27. Berry, James, Greg Fischer, and Raymond Guiteras. "Eliciting and Utilizing Willingness to Pay: Evidence from Field Trials in Northern Ghana.” IGC Working Paper 12/0188, 2012.

http://personal.lse.ac.uk/fischerg/Assets/BFG-BDM-April2012.pdf\%5Cnhttp://www.economics.cornell.edu/jwb295/BFG-BDM-April-2012.pdf.

28. Plappally, Anand Krishnan, Ankur Hasija, Jonathan Kusins, Malini Jhaver, Allen Chee, Anirudha Panditrao, and Niket Kumar Singh. "Water Use and Related Costs at Households in Western and Northern Parts of India." Hydrol Current Res 4, no. 3 (2013). doi:10.4172/2157-7587.1000158.

29. Shotyk, William, Michael Krachler, and Bin Chen. "Contamination of Canadian and European Bottled Waters with Antimony from PET Containers." Journal of Environmental Monitoring 8, no. 2 (2006): 288. doi:10.1039/b517844b.

30. Duary, Nabakumar. "Traditional Hira Potters of Lower Assam.” Indian Journal of Traditional Knowledge 7, no. 1 (2008): 98-102.

31. Roux, Valentine. The White Matka-Ethnography of a Water Jar. First. Jodhpur: Rupayan Sansthan, 2015.

32. Tyeryar, By Molly, Jack Reed, Caroline Hackett, Meredyth Gilmore, and Lydia Abebe. "A Study of the Feasibility of Creating a Ceramic Water Filter Factory in Limpopo Province, South Africa.” Public, no. December (2011): 119-27.

33. Rayner, Justine, Brian Skinner, and Daniele Lantagne. "Current Practices in Manufacturing Locally-Made Ceramic Pot Filters for Water Treatment in Developing Countries.” Journal of Water Sanitation and Hygiene for Development 3, no. 2 (June 1, 2013): 252 LP-261. http://washdev.iwaponline.com/content/3/2/252.abstract. 
International Journal for Service Learning in Engineering, Humanitarian Engineering and Social Entrepreneurship Vol. 13, No. 1, pp. 53-66, Spring 2018

ISSN 1555-9033

34. Foster, George M . "Pottery-Making in Bengal.” Southwestern Journal of Anthropology 12, no. 4 (1956): 395-405.

35. Banerji, Ratnadeep. "Cultivating Rural Technology for Development.” Press Information Bureau, Government of India, . December 26, 2016. http://pib.nic.in/newsite/printrelease.aspx?relid=155839.

36. Johnson, Sophie; Teshamulwa, Okioga. "Project Report for Pure Home Water, Ghana Independent Study , Advisor : Simon Johnson.” Massachussets, 2007.

37. Miller, Travis Reed, and Travis Russell Watters. "Pure Home Water Ceramic Filter Manufacturing Manual.” Environmental Engineering, 2010. http://web.mit.edu/watsan/Docs/Student Reports/Ghana/Final Report PHW Factory Manual RMiller and TWatters 5-24-10.pdf.

38. Baumgartner, Jill, Susan Murcott, and Majid Ezzati. “Reconsidering 'Appropriate Technology': the Effects of Operating Conditions on the Bacterial Removal Performance of Two Household Drinking-Water Filter Systems." Environ. Res. Lett. Environ. Res. Lett 2, no. 2 (2007): 24003-6. doi:10.1088/17489326/2/2/024003.

39. Hagan, JM, N Harley, D Pointing, and M Sampson. Resource Development International-Cambodia Ceramic Water Filter Handbook. Phnom Penh, Cambodia. 1.1. Engineers Without Borders, Australia and RDIC, Cambodia, 2009. http://potterswithoutborders.com/wp-content/uploads/2011/12/RDIC-CeramicFilter-Manual.pdf.

40. Malapane, Tshepo Alex, Caroline Hackett, Vhonani Netshandama, and James Smith. "Ceramic Water Filter for Point-of-Use Water Treatment in Limpopo Province, South Africa.” In 2012 IEEE Systems and Information Engineering Design Symposium, SIEDS 2012, 107-11, 2012. doi:10.1109/SIEDS.2012.6215150.

41. Dumont, Louis. “A Remarkable Feature of South Indian Pot-Making.” Man 52 (1952): 81-83.

42. Sinopoli, Carla M. "Seeking the Past through the Present: Recent Ethnoarchaeological Research in South Asia." Asian Perspectives 30, no. 2 (1991): 177-92.

43. The Ceramics Manufacturing Working Group. Best Practice Recommendations for Local Manufacturing of Ceramic Pot Filters for Household Water Treatment, Ed. 1. Atlanta, GA, USA: CDC (2011).

44. Satankar, R., Kaurwar, A., Gupta, S., Usha, K., Azeko, S.T., Soboyejo, W. O., Soboyejo, A.B.O. Plappally A. "Role of Equine Ordure in Enhancing Physical and Mechanical Properties of Natural Bio-Active Composites." In Advanced Polymeric Materials for Sustainability and Innovations, edited by Didier Rouxel Sajith Rahman, Sabu Thomas, Nandakumar Kalarikkal, 1st ed. Apple Academic Press, CRC Press, 2017.

45. Satankar, R. K., Kaurwar, A., Gupta, S., Plappally, A. "Horse Dung and Soil Based Composites for Construction of Aesthetic Shelves in Rural Homes of Western Rajasthan." In Proceedings of the 4th National Conference on Innovations in Indian Science, Engineering and Technology, NCISET, Focus: Rural Housing. New Delhi, India: CSIR-NPL, 2017.

46. Handler, Jerome. "Pottery Making in Rural Barbados." Southwestern Journal of Anthropology 19, no. 3 (1963): 314-34.

47. Henry, Michael. "Designing a Low-Cost Ceramic Water Filter Press.” International Journal for Service Learning in Engineering 8, no. 1 (2013): 62-77.

48. Barsoum, Michel. Fundamentals of Ceramics. New York, USA: Taylor and Francis Group, 2003.

49. Ravi, M R, P L Dhar, and Sangeeta Kohli. "Energy Audit and Improvement of an Updraught Pottery Kiln." SESI 17 (2007): 1-20.

50. Yakub, I., A. Plappally, M. Leftwich, K. Malatesta, K.C. Friedman, S. Obwoya, F. Nyongesa, et al. "Porosity, Flow, and Filtration Characteristics of Frustum-Shaped Ceramic Water Filters." Journal of Environmental Engineering (United States) 139, no. 7 (2013). doi:10.1061/(ASCE)EE.1943-7870.0000669.

51. Annan, Ebenezer. "Clay Ceramic Materials for Water Filtration: Properties, Processing and Performance." Abuja, Nigeria, 2016. https://repository.aust.edu.ng/xmlui/bitstream/handle/123456789/357/Ebenezer Annan.pdf? sequence $=1 \&$ isAllowed $=\mathrm{y}$. 
International Journal for Service Learning in Engineering, Humanitarian Engineering and Social Entrepreneurship Vol. 13, No. 1, pp. 53-66, Spring 2018

ISSN 1555-9033

52. Musah, Abdulai. "Modeling and simulation of stress distribution and crack configuration of the geometry of Ceramic Water Filter .” Abuja, Nigeria, 2011. http://repository.aust.edu.ng/xmlui/handle/123456789/409.

53. Salvinelli, C, and A C Elmore. "Assessment of the Impact of Water Parameters on the Flow Rate of Ceramic Pot Filters in a Long-Term Experiment." Water Science and Technology: Water Supply 15, no. 6 (December 9, 2015): 1425 LP-1432. http://ws.iwaponline.com/content/15/6/1425.abstract.

54. Salvinelli, Carlo. "Lifetime and Effectiveness Evaluation of Ceramic Pot Filters," 2016.

55. Ashby, M. F., Jones D. R. H. Engineering Materials 2: An Introduction to Microstructures, Processing and Design. 2nd Editio. Great Briian: Butterworth-Heinemann, 1998.

56. Plappally, A.K., I. Yakub, L.C. Brown, W.O. Soboyejo, and A.B.O. Soboyejo. "Physical Properties of Porous Clay Ceramic-Ware." Journal of Engineering Materials and Technology, Transactions of the ASME 133, no. 3 (2011). doi:10.1115/1.4004158.

57. Gladkov S. Dielectric Properties of Porous Media,. First. New York: Springer Verlag, 2003.

58. Rice R W. "The Compressive Strength of Ceramics." In Ceramics in Severe Environments. Materials Science Research, Vol. 5, edited by Palmour H Kriegel W W, 195-96. New York, USA: Plenum Press, 1971. https://link.springer.com/chapter/10.1007/978-1-4684-3141-4_14.

59. Karaman, Sedat, Sabit Ersahin, and Hikmet Gunal. "Firing Temperature and Firing Time Influence on Mechanical and Physical Properties of Clay Bricks." Journal of Scientific and Industrial Research 65, no. 2 (2006): 153-59.

60. Paulinus Chigbu, Parveen Salina. "Bacteriological Analysis of Water." In Handbook of Water Analysis, edited by Gelder Leen Nollet Leo, First., 115-62. CRC Press, Taylor and Francis Group, 2014.

61. Brown, Joe, and Mark Sobsey. "Independent Appraisal of Ceramic Water Filtration Interventions in Cambodia: Final Report by UNC School of Public Health," 2006.

62. TFS. "One Shot ${ }^{\mathrm{TM}}$ TOP10 Chemically Competent E. Coli." MANO001491, 2016. https://www.thermofisher.com/order/catalog/product/C404010.

63. CPCB. "Status of Water Quality in India- 2012 (Monitoring of Indian National Aquatic Resources Series: MINARS/36 /2013-14 STATUS)," 2013. http://www.cpcb.nic.in/WQ_Status_Report2012.pdf.

64. Gorchev, H G, and G Ozolins. "WHO Guidelines for Drinking-Water Quality." WHO Chronicle. Vol. 38, 2011. doi:10.1016/S1462-0758(00)00006-6.

65. Brown J, Proum S, Sobsey M. "Escherichia Coli in Household Drinking Water and Diarrheal Disease Risk: Evidence from Cambodia." Water Science and Technology 58, no. 4 (2008): 757-63.

66. Williams, Alison, and Charlotte Youngblood. "Water Stories : Expanding Opportunities in Small-Scale Water and Sanitation Projects.” Water Stories, 2006, 98. 